\title{
CORPORATE RISK DISCLOSURE: THE EFFECT OF CORPORATE GOVERNANCE
}

\author{
Arisona Ahmad $^{1)^{*}}$, Muhammad ${ }^{2)}$, Dwi Narullia ${ }^{3)}$ \\ ${ }^{1}$ Jurusan Manajemen Agribisnis, Politeknik Negeri Jember \\ email: arisona_ahmad@polije.ac.id \\ ${ }^{2}$ Fakultas Ekonomi dan Bisnis, Universitas Negeri Malang \\ email: muhammad.fe@um.ac.id \\ ${ }^{3}$ Fakultas Ekonomi dan Bisnis, Universitas Negeri Malang \\ email: dwi.narullia.fe@um.ac.id
}

\begin{abstract}
This research investigates the role of corporate governance on the disclosure of corporate business risk management with leverage and company size as control variables. Research data were taken from a company that classified as LQ 45 on the Indonesian stock exchange from 2015 to 2018. This research finds that disclosure of business risk management as a sign that management has managed the company with the good attitude increases along with increased corporate governance activities. Leverage and company size also affect company policies regarding the disclosure of corporate business risks. Overall, the results of this study are consistent with the assumption that corporate governance affects company policies regarding business risk disclosure. However, in contrast to the initial hypothesis, the composition of the board commissioners reduces the risk management disclosure activity in the company. This is because the board of commissioners considers that business risk disclosure can increase costs and reduce its competitive advantage so that investors will respond negatively. Apart from these variables, this study contributes to agency theory, where the findings of this study indicate the confirmation of the application of theory in the context of this study.
\end{abstract}

Keywords: Corporate Governance; Risk Management Disclosure; Board of Commissioners

\begin{abstract}
ABSTRAK
Penelitian ini menyelidiki peran tata kelola perusahaan terhadap pengungkapan manajemen risiko bisnis perusahaan dengan leverage dan size perusahaan sebagai variable control. Data penelitian meliputi perusahaan yang tergolong LQ 45 di bursa efek Indonesia dari tahun 2015 hingga 2018. Penelitian ini menemukan bahwa pengungkapan manajemen risiko bisnis sebagai tanda bahwa manajemen telah berperilaku baik dalam mengelola perusahaan meningkat seiring dengan peningkatan aktivitas tata Kelola perusahaan. Leverage dan ukuran perusahaan juga mempengaruhi kebijakan perusahaan mengenai pengungkapan risiko bisnis perusahaan. Secara keseluruhan, hasil penelitian ini konsisten dengan dugaan bahwa tata kelola perusahaan mempengaruhi kebijakan perusahaan mengenai pengungkapan risiko bisnis. Namun, berbeda dengan hipotesis awal komposisi dewan komisaris menurunkan aktivitas pengungkapan manajemen risiko diperusahaan. Hal ini dikarenakan dewan komisaris menimbang bahwa pengungkapan risiko bisnis dapat meningkatkan biaya serta menurunkan keunggulan kompetitif perusahaan sehingga akan direspon negatif oleh investor. Selain variabel tersebut, penelitian ini berkontribusi pada teori agensi dimana temuan yang ada menunjukkan konfirmasi dari penerapan teori di dalam konteks penelitian.
\end{abstract}

Kata Kunci : Tata Kelola Perusahaan; Pengungkapan Manajemen Risiko;, Dewan Komisaris 


\section{INTRODUCTION}

Not only popular, but corporate governance also shows its existence with many studies that prove that the application of good corporate governance (GCG) has become one of the indicators of company success. Furthermore, the application of good governance is expected to improve company performance, to increase the value of the company and provide benefits for shareholders (Bai et al., 2004). In addition to improving company performance, the GCG can also enhance the quality of corporate profits (Ghofar \& Islam, 2013, 2015). In the development of the business world at present, it is not enough for business actors to only ensure that management is running efficiently, but also GCG instruments are needed to ensure that company management activities are carried out properly. (Kaihatu, 2006; Khalid et al., 2016; Urban, 2019).

The Global Risk Management Survey shows that more than 83 percent of companies worldwide had a corporate risk management program (Deloitte, 2019). Risk is a reality that cannot be separated from company activities or decision making. Risks need to be managed properly so as not to cause a greater negative impact on the company. Many benefits will be obtained by the company when able to manage risk well. As explained by Power (2004), companies that proactively manage their risks besides being able to detect fraud but can also improve the quality of financial statements (Wiseman \& Bromiley, 1996; Yatim, 2010). Besides, good risk management is believed to improve company performance (Aebi et al., 2012; COSO, 2004; Pagach \& Warr, 2010; Simkins \& Ramirez, 2008; Wiseman \& Bromiley, 1996) and will increase value and excellence competitive shareholders (Nocco \& Stulz, 2006; Rosli et al., 2017; Wu et al., 2016). Aabo (2006) argues that companies that conduct risk management well can increase satisfaction for stakeholders. Implementation of good risk management will generate profits and ensure the sustainability of the company's operations that lead to shareholder trust.

Research conducted by Nocco \& Stulz (2006) shows that no method can assess whether the risk management policies implemented in a company are good or not. However, to assess the performance of the risk committee's chairman, the board and shareholders can evaluate by looking at the extent to which risks can be identified and managed. The results of the identification and management of risk are information that must be disclosed because it can be useful for decision making. Considering the characteristics of companies in Indonesia whose share ownership is concentrated and much owned by families (Nuryaman, 2009), the agency theory developed by Schleiver \& Vishny (1986) is suitable for this study. Agency theory developed by Schleiver \& Vishny (1986), illustrates the problems that arise between majority share ownership and minority stock ownership that occurs in a company. It is feared that the majority of shareholders will have more control over company policies and thus expropriate minority shareholders. In order to protect the interests of minority shareholders, the company must have a certain rule that is good corporate governance (Schleiver \& Vishny, 1986).

So far, the research that links corporate governance and risk management has shown inconsistent results. Research by Yatim (2010) and Subramaniam, Mcmanus, \& Zhang (2009) shows that companies that have a greater proportion of independent boards on the board structure tend to build risk management committees separately from the audit committee. On the other hand, Desender (2007) proves that the independent board of commissioners in the organizational structure has no relationship with increasing the level of corporate 
business risk management. The independent board of directors only has a significant relationship to the company's business risk management if there is a separation between the supervisory function and the management function which shows an increase in the level of risk management.

Based on the background that has been described, the role of business risk management as a manifestation of GCG is very important in the process of a company carrying out all its activities. It fits for companies in Indonesia to pay more attention to corporate risk management as a manifestation of good corporate governance. However, in practice, not all companies have implemented integrated risk management. This research is also to answer the question of whether the application of good corporate governance can affect the level of risk management disclosures conducted by the company.

\section{LITERATURE REVIEW}

\section{Agency Theory}

Jensen \& Meckling (1976) define agency relationships as contracts, where one or several people (principals) employ other people (agents), in this case, management is given a mandate by shareholders to carry out tasks in managing a company. In other words, the principal or shareholders delegate their authority to management to make and carry out decisions to achieve goals. Eisenhardt (1989) explains that agency theory is based on the assumption, that as a human being, management tends to have a selfish nature, makes all decisions and behaviours that are taken will benefit themselves (self-interest). Furthermore, management is also described as having risk aversion. On the other hand, management in an organization is described as many individuals who have a variety of interests in it. Therefore, management will be vulnerable to conflict.
The next assumption is about information, information is very important in a business organization, as a basis for decision making in achieving goals. Seeing the importance of information, in a business organization information is seen as a commodity that is traded. With the underlying assumptions and the separation between shareholders and management, a conflict will arise between them. Barnhart \& Rosenstein (1998) states that the way to overcome the agency conflict problem is by implementing good corporate governance. The development of agency theory is not only interpreted as a conflict between the principal and agent, but a problem that arises because the majority shareholder have more control over company policies, and tend to harm minority shareholders (Schleiver \& Vishny, 1986). To protect the interests of minority shareholders from the majority shareholder, the company and its management must have and run a set of specific regulatory mechanisms, namely what is called good corporate governance (Schleiver \& Vishny, 1986).

\section{The Effect of Board of Commissioners Composition on Risk Management Disclosures}

Jensen \& Meckling (1976) identified two ways to reduce managers' opportunities to take actions that are detrimental to investors, one of which is by outside investors overseeing management. One form of supervision carried out by investors is to regulate the mechanism of characteristics of the board of commissioners. The characteristics of the board of commissioners have a significant role in encouraging managers to implement risk management and effective internal control (Gordon et al., 2009; Yatim, 2010; Zhang et al., 2007). The independence that is owned by an independent commissioner is expected to function as the most effective monitoring and policy control tool and manager's activities. Outside parties such as 
independent commissioners must have the expertise and objectivity to control and give advice to a manager. Therefore, an independent board of commissioners is expected to be more aware and objective to provide a superior monitoring function to the company's internal control and corporate risk management (Yatim, 2010).

The supervisory role of the board of commissioners is expected to reduce agency problems between shareholders and management. Therefore, the market will tend to support the existence of independent commissioners (Lefort \& Urzúa, 2008). Besides, an independent board will provide a balance for managers as insiders so that managers cannot take advantage of their positions at the expense of the interests of shareholders (Yunos, 2011). Not only the independence factor, Suhaimi \& Mohamad Naim (2017) states that the level of supervision by the board of commissioners which is largely influenced by the quality and the educational background can also increase business risk management activities in the company. Based on this, the following hypothesis is proposed:

H1: The composition of the board of
commissioners influences the
disclosure of corporate risk
management

The Effect of Composition and Expertise Background of the Audit Committee on Corporate Risk Management Disclosures

The Audit Committee, as part of the monitoring system, is also considered to make a positive contribution to the implementation of internal control and risk management. Accounting and financial expertise and the educational background of audit committee members are expected to increase the effectiveness of internal control and risk management. Weaknesses in internal control are found more in companies whose audit committees lack accounting and financial expertise (Zhang et al., 2007).

Dionne \& Triki (2005) also examined whether the new rules on corporate governance are known as Sarbanes Oxley which provides additional requirements regarding the composition and background knowledge related to accounting and financial audit committees that exist in the company. This research proves that the performance appraisal of the company's risk management increases when the company has a composition of the board of commissioners and an audit committee that is independent and has financial knowledge and is highly educated. In addition, the study also found that the requirements of the composition of the audit committee and independence were beneficial to shareholders. Based on this, the following hypothesis is proposed:

H2: The audit committee composition and expertise influence the disclosure of corporate risk management

\section{The Effects of Reputation and Opinion of External Auditors on Risk Management Disclosures}

Auditor independence was identified as having a positive relationship with internal control. Changes in auditors are found to be more likely in companies with weaknesses in internal control (Zhang et al., 2007). Therefore external auditors are one of the important mechanisms in internal control and risk management mechanisms in a company. Companies that use external auditors with greater reputations will have the possibility of reducing financial reporting and internal control problems (Doyle et al., 2007). According to Cohen, Krishnamoorthy, \& Wright (2004) companies with big four auditors encourage higher quality internal control mechanisms. In general, big four auditors can influence their clients' internal control systems by making improvement recommendations and design (Subramaniam et al., 2009) in order to 
meet the need for maintenance of audit quality and protection of their reputation. Based on this, the following hypothesis is proposed:

\section{H3: The reputation and opinion of the external auditor influences the disclosure of risk management}

\section{The Effect of Frequency of Board of Commissioners' Meetings on the Disclosures of Corporate Risk Management}

Other board's characteristics, such as the expertise and the frequency of meetings also postulate a positive relationship with the establishment of a risk management committee. Research conducted by DeZoort, Hermanson, Archambeault, \& Reed (2002) shows that a greater frequency of meetings is associated with a reduction in incidents of financial reporting problems and improvement in the quality of external audits. The frequency of meetings encourages the board of commissioners to obtain information on the condition of the company more intensive, relevant, and timely, especially about risks and better quality of internal control. The higher frequency of meetings can provide positive signals to users of financial statements on the company's performance in achieving the company's goals. The high frequency of attendance from the board of commissioners expected to increase the knowledge of members, and broad knowledge is suspected to increase the attention to the risk management in the company (Yatim, 2010). Based on this, the following hypothesis is proposed:

H4: The frequency of the board of commissioners' meeting influence the disclosure of corporate risk management.

\section{RESEARCH METHODS}

\section{Population and Samples}

This research is a quantitative study using data obtained from the company's financial statements and annual reports. This research on the effect of corporate governance on the disclosure of business risk management of this company uses the object of research in the form of a company listed on the Indonesia Stock Exchange (IDX) included in the LQ45 index with a 4-year observation period, 2015-2018.

The sample selection in this study is to use a purposive sampling method. The following are the criteria for selecting the sample of this study.

Table 1 Sample Selection Criteria

\begin{tabular}{|c|l|c|}
\hline NO & \multicolumn{1}{|c|}{$\begin{array}{c}\text { SAMPLING } \\
\text { CRITERIA }\end{array}$} & TOTAL \\
\hline $\mathbf{1}$ & $\begin{array}{l}\text { Companies included in } \\
\text { the Indonesia Stock } \\
\text { 2x } 2\end{array}$ & $\begin{array}{l}\text { Exchange LQ45 index } \\
\text { Companies that do not } \\
\text { have complete data } \\
\text { needed in research }\end{array}$ \\
\hline & $\begin{array}{l}\text { Companies used as } \\
\text { research samples }\end{array}$ & 31 \\
\hline
\end{tabular}

Based on the criteria used in the selection of samples in this study, 31 companies were selected as the research samples. This research was conducted using data in the 2015-2018 period so that the total observation data in this study was 124 observations.

\section{Measurement of Company Risk Management Disclosures}

An adequate risk management system must meet certain requirements so that its reliability in supporting the successful implementation of the company's risk management (Tjahjadi, 2011). COSO (2004) states that a company's risk management must have one element, namely risk disclosure as an indication that the company carries out overall corporate risk management. Therefore, this study uses business risk disclosure in corporate financial reporting as an indication that management has 
implemented corporate risk management that is disclosed in the annual report as a proxy. Companies that have disclosed the description of business risks in the annual report can be concluded that the company has carried out risk management. The company information that is sampled in this study reveals risk management in the annual report as follows.

Table 2. The Existence of Corporate Risk Management Disclosures

\begin{tabular}{|l|c|c|}
\hline $\begin{array}{l}\text { Risk } \\
\text { Management } \\
\text { Disclosures }\end{array}$ & Existence & Percentage \\
\hline Exist & 124 & 100 \\
\hline Not Exist & 0 & 0 \\
\hline Total & 124 & 100 \\
\hline
\end{tabular}

Based on the information on the table above, all the sample companies taken in this study, 124 annual reports have revealed risk management. This means the majority of companies incorporated in LQ 45 have implemented integrated risk management. To analyze the effect of independent variables on risk management disclosures in this study, each company counts how many aspects of risk management are disclosed in the annual report. The more aspects disclosed in the annual report, the higher the disclosure of business risk management by the company.

\section{Measurement of Corporate Governance}

The measurement of corporate governance variables in this study uses a proxy called the Good Corporate Governance Scoring Index, represented by the composition of the board of commissioners, the composition and background of the audit committee's expertise, the quality and opinion of external audits, and the frequency of board meetings. According to Gwenda \& Juniarti (2013), high good corporate governance scoring index shows that the implementation of corporate governance is getting better. If the implementation of corporate governance is getting better, then it will also have an impact on high company value.

In this research, the components of corporate governance criteria are divided into four, namely: the composition of the board of commissioners, reputation and external audit opinion, composition and background of the expertise of the audit committee, the frequency of the board of commissioners meeting which is an assessment that a company has implemented good corporate governance.

\section{Measurement of Control Variables}

Leverage is an instrument to measure a company's ability to meet its financial obligations consisting of shortterm debt and long-term debt. Pagach \& Warr (2010) argues that companies that can meet their financial obligations properly will take the initiative to improve risk management programs properly. Leverage in this study is represented by the debt to equity ratio. The debt to equity ratio can be calculated using the following formula (Liebenberg \& Hoyt, 2003):

$$
\begin{aligned}
& \text { Debt to Equity Ratio } \\
& \qquad=\frac{\text { Total Debt }}{\text { Total Capital }} \times 100 \%
\end{aligned}
$$

The size of the company is the size of assets owned by the company. Desender (2007) argues that the need to implement integrated enterprise risk management requires effective risk management techniques, companies that have a larger scale have the greater ability also to implement integrated enterprise risk management. Measurement of company size using total assets as a proxy has been widely used by previous researchers, one of which was conducted by Liebenberg \& Hoyt (2003) which states that risk management is also influenced by company size factors, where company size 
is proxied by the logarithmic value of total assets or can be written as follows.

$$
\text { Size }=\log (\text { Total Aset })
$$

\section{RESULTS AND DISCUSSION}

\section{Hypothesis Test}

Hypothesis testing is intended to determine whether the individual variables affect the dependent variable. Ghozali (2018) argues that in hypothesis testing, we want to know the effect of an independent variable in explaining the dependent variable. The test is carried out by looking at the level of significance of each variable with a level of significance $(1 \%, 5 \%, 10 \%)$, The description of the results of variable testing is presented in the table below.

Table 3 Summary of Hypothesis Testing

\begin{tabular}{|l|c|c|}
\multicolumn{1}{|c|}{ Rariable } & Coefficient & Conclusion \\
\hline $\begin{array}{l}\text { Board of } \\
\text { Commissioners } \\
\text { Composition } \\
\text { (KDK) }\end{array}$ & $-3.388^{*}$ & Accepted \\
\hline $\begin{array}{l}\text { Audit } \\
\text { Committee } \\
\text { Composition } \\
\text { and Expertise } \\
\text { (KKA) }\end{array}$ & $4.364^{* *}$ & Accepted \\
\hline $\begin{array}{l}\text { Auditor's } \\
\text { Reputation and } \\
\text { Opinion (ROA) }\end{array}$ & 0.460 & Rejected \\
\hline $\begin{array}{l}\text { Frequency of } \\
\text { Board of } \\
\text { Commissioners' } \\
\text { Meetings } \\
\text { (FRDK) }\end{array}$ & $0.043^{*}$ & Accepted \\
\hline $\begin{array}{l}\text { Debt to Equity } \\
\text { Ratio (DER) }\end{array}$ & $0.281^{* * *}$ & Accepted \\
\hline $\begin{array}{l}\text { Company Size } \\
\text { (SIZE) }\end{array}$ & $0.788^{*}$ & Accepted \\
\hline
\end{tabular}

$* 1 \%$ level of significance

** $5 \%$ level of significance

$* * * 10 \%$ level of significance
The Effect of Board of Commissioners Composition on Corporate Risk Management Disclosures

This research can prove that the composition of the board of commissioners influences the disclosure of the company's business risk management. The regression coefficient value of the composition of the board of commissioner's variable is $-3,388^{*}$. This result shows that the composition of the company's board of commissioners negatively affects the disclosure of the company's business risk management. Although many previous studies indicate that as the increase in corporate governance activities embodied in the composition of the board of commissioners will increase the disclosure of risk management conducted by management, the results of this study contradict with the previous research. The results of this study show that the composition of the board of commissioners decreases the disclosure of business risks carried out by management. This is because disclosure of risk in the annual report is considered to reduce the competitive advantage of their products in the market, the presence of competitive advantage is more positively responded by investors compared to risk disclosures made by management, so disclosures tend to be avoided by the board. Samaha, Khlif, \& Hussainey (2015) argue that the decline in competitive advantage is due to the increased costs incurred by management to make disclosures. This significant increase in costs can increase product prices and reduce the company's competitive advantage in terms of prices in the market. Therefore the board tends to minimise the disclosure activities to reduce costs, so that it is expected that their competitive advantage and profits can be reached.

The Effect of Composition and Expertise Background of the Audit 


\section{Committee on Corporate Risk Management Disclosures}

The audit committee is formed by the board of commissioners to assist and carry out the duties of the board of commissioners. Audit committee members must have expertise and experience in the audit field and other qualities required. The bigger the size of company, the greater the complexity possessed by the company. This will make it difficult for the board of directors to oversee the company, therefore the board often delegates its duties and responsibilities in terms of supervision and management to employees. This will encourage the board of directors to ask the audit committee to assist the board of directors in terms of oversight to company management to ensure that management works in accordance with the objectives set by the company. The audit committee as part of the supervision system is also considered to make a positive contribution to the company's internal control system and the company's business risk management (Zhang et al., 2007). Audit committee competence is much influenced by the educational background obtained by the audit committee members. Zhang et al. (2007) state that the weaknesses of risk management and internal control of a company are more commonly found in companies that have less accounting and financial expertise on the audit committee.

Based on the results, the composition and background of the audit committee's expertise positively affect the disclosure of the company's business risk management. The results of this study reinforce the results of previous studies conducted by Dionne \& Triki (2005). Dionne \& Triki (2005) states that the composition of the audit committee can increase the risk management activities carried out by the company. This is because the existence of an independent audit committee will tend to maintain their performance as a function of supervision of management, this is also because an independent audit committee will tend to maintain the reputation of the shareholders and external parties.

\section{The Effects of Reputation and Opinion of External Auditors on Disclosure of Corporate Business Risk Management}

Companies that use external auditors with a greater reputation will have the possibility of reducing the problems of financial reporting and internal control (Sari, 2013). In that research Sari (2013) defines the reputation of external auditors as referring to the Public Accounting Firm (KAP) who has a good name, achievements and has the trust of the public. KAP which is included in the bigfour categories is a KAP that is considered to have a good reputation and has gained good public trust. Big four auditors are auditors who have an excellent reputation, big four auditors will tend to maintain their reputation as competent auditors. Therefore, the big four auditors will encourage their clients to implement corporate governance (Subramaniam et al., 2009).

Several previous studies state that the use of external auditors classified as big four has no influence on the risk management activities in a company (Andarini \& Januarti, 2012; Subramaniam et al., 2009). The results of testing the hypotheses in this study reinforce the results of research conducted by Subramaniam et al. (2009) and Andarini \& Januarti (2012), the reputation and opinion of external auditors classified as big four did not affect the disclosure of the company's business risk management. This is because not all companies listed on the Indonesia Stock Exchange use the services of a big four external auditor, so the use of the services of a big four external auditor cannot be concluded to significantly influence the increase in the company's business risk management activities. 
The Effect of Frequency of Board of Commissioners' Meetings on Corporate Risk Management Disclosures

The perseverance of a board of commissioners can be seen from the frequency of attendance of the meeting and the behavior of the board members in the meeting. Such behavior includes the number of board members who attend meetings, preparations before board meetings, and participation by board members in board meetings (Yatim, 2010). The board of commissioners will increase the frequency of their meetings to discuss the results and recommendations given by the risk management committee related to the risks experienced by the company and their solutions. The results of hypothesis testing in this study reinforce the results of previous studies, namely the frequency of meetings conducted by the board of commissioners significantly affect the disclosure of the company's business risk management. The larger the company, the greater the risks and problems faced. The board of commissioners as the holders of responsibilities given by the shareholders to maintain the effectiveness of the company's goals will try to find solutions to the risks and problems experienced by the company. To find solutions to problems, the board of commissioners will hold an intensive meeting.

\section{The Effect of Leverage on Corporate Risk Management Disclosures}

Leverage is a ratio used in measuring a company's ability to meet its financial obligations which consist of short-term debt and long-term debt. Pagach \& Warr (2010) argues that companies that can meet their financial obligations properly will take the initiative to improve good risk management programs. Companies that have high debt tend to have high agency costs, so this can lead to high financial risk. Companies that have high leverage tend to have high going-concern risk (Subramaniam et al., 2009).
The test results of the control variable that is leverage in this study showed a significant influence on the disclosure of the company's business risk management. The coefficient value of this variable is $0.281^{* * *}$ which means the leverage ratio positively affects the disclosure of the company's business risk management. This research supports a study conducted by several previous researchers (Kumalasari et al., 2014; Pagach \& Warr, 2010; Utomo \& Chariri, 2014). According to agency theory, creditors and shareholders of companies that have high-risk debt structures tend to require management to disclose more complete information in annual reports, of course, shareholders consider that management policies in managing debt are important to them, companies that have comparisons Large debt in the company's capital structure is a risk for shareholders. With a high level of debt, the company has an obligation to pay interest to creditors, therefore it will affect the dividends that will be distributed to shareholders. While creditors, see that companies that have a high debt structure will have a high risk of not being able to fulfill their debt obligations. Therefore, shareholders and creditors tend to demand management to disclose all risks that could affect them in the annual report prepared by management.

\section{The Effect of Company Size on Corporate Risk Management Disclosures}

Company size is the size of an asset owned by a company. Large companies tend to establish and increase activities that are considered beneficial for these companies (Chen et al., 2009), large companies have a great potential to have bigger agency problems, because large companies tend to be difficult to supervise. more thoroughly (Jensen \& Meckling, 1976). Some previous research prove that company size has a significant effect on improving corporate risk management (Andarini \& Januarti, 2012; Desender, 
2007; Subramaniam et al., 2009). Andarini \& Januarti (2012) argue that the larger the company, the more likely it will be to establish and enhance the activities of corporate governance and business risk management of the company, this is because the company wants to maintain the good name of the company.

Based on the results of research conducted, company size as a control variable used in this study shows that company size has a significantly positive influence on the disclosure of the company's business risk management. Large companies tend to want to maintain their reputation by increasing activities that benefit them, one of which is the company's business risk management (Andarini \& Januarti, 2012). Desender (2007) believes that the need to implement integrated enterprise business risk management requires effective risk management techniques. Companies that have a larger scale also have a greater ability to implement integrated business risk management in the company. This is because companies that have a larger scale have more resources to implement the company's business risk management better.

\section{CONCLUSIONS AND SUGGESTIONS}

This study aims to investigate about the effect of corporate governance on the disclosure of the company's business risk management, as an indicate that the company has implemented corporate risk management. This research was conducted at companies classified as LQ 45 on the Indonesia Stock Exchange (IDX) with the 2015-2018 research period. This research proves that there is a significant influence between the composition of the board of commissioners on the disclosure of the company's business risk management. However, this significant influence shows a negative direction, the results of this study actually contradict the results of research conducted by Subramaniam et al. (2009), Yatim (2010) and Dionne \& Triki
(2005). In this study also succeeded in proving that the composition and background expertise of the audit committee has a positive and significant effect on the disclosure of the company's business risk management. In addition to the composition of the board of commissioners and the audit committee, this study also provides empirical evidence that the frequency of meetings conducted by the board of commissioners has a positive and significant effect on the disclosure of corporate risk management. This is due to the greater problems faced by companies increasingly demanding the board of commissioners to get an understanding of the problems and solutions that must be done, thus demanding the members of the board of commissioners to be more active in holding meetings. It can also increase risk management activities. Increased risk management activities and the frequency of meetings disclosed can be positive signals to users of financial statements.

Leverage and company size which are the control variables in this study also indicate a significant influence on the disclosure of company risk management. On the other hand, the results of this study failed in proving that the use of external auditors classified as big four had a significant influence on the disclosure of corporate risk management. This can be since the use of external auditors classified as big four is only used to enhance the reputation alone by the company and the big four external auditors in this case only pay attention to financial risk monitoring.

\section{ACKNOWLEDGMENT}

Thanks are conveyed to all parties who helped carry out this research well. The gratitude goes to State Polytechnic of Jember and Universitas Negeri Malang, which has provided support ranging from licensing until administration. 


\section{REFERENCE}

Aabo, T. (2006). Stakeholder versus Shareholder Satisfaction in Corporate Risk Management. FSR Forum, 8(3), 6-12.

Aebi, V., Sabato, G., \& Schmid, M. (2012). Risk management, corporate governance, and bank performance in the financial crisis. Journal of Banking and Finance, 36(12), 32133226.

https://doi.org/10.1016/j.jbankfin.201 1.10 .020

Andarini, P., \& Januarti, I. (2012). Hubungan Karakteristik Dewan Komisaris Dan Perusahaan Terhadap Keberadaan Komite Manajemen Risiko Pada Perusahaan Go Public Indonesia. Jurnal Akuntansi Dan Keuangan Indonesia, 9(1), 83-99. https://doi.org/10.21002/jaki.2012.06

Bai, C. E., Liu, Q., Lu, J., Song, F. M., \& Zhang, J. (2004). Corporate governance and market valuation in China. Journal of Comparative Economics, 32(4), 599-616. https://doi.org/10.1016/j.jce.2004.07. 002

Barnhart, S. W., \& Rosenstein, S. (1998). Board and Firm Performance: An Empirical Analysis. The Financial Review, 33(303), 1-16. https://doi.org/10.1111/j.15406288.1998.tb01393.x

Chen, L. (Glenda), Kilgore, A., \& Radich, R. (2009). Audit committees: Voluntary formation by ASX non-top 500. Managerial Auditing Journal, 24(5), 475-493. https://doi.org/10.1108/02686900910 956829

Cohen, J., Krishnamoorthy, G., \& Wright, A. (2004). The Corporate Governance Mosaic and Financial Reporting Quality. Journal of Accounting Literature, 87-152.

COSO. (2004). Enterprise Risk Management-Integrated Framework. In Committee of Sponsoring Organizations of the Treadway
Commission

$(\mathrm{COSO})$

(Issue

September).

https://doi.org/10.1002/97811192019 39.app4

Deloitte. (2019). Global risk management survey (11th edition): Reimagining risk management to mitigate looming.

Desender, K. A. (2007). On the determinants of enterprise risk management implementation. SSRN Electronic

Journal. https://doi.org/10.4018/978-1-60566346-3.ch006

DeZoort, F. T., Hermanson, D. R., Archambeault, D. S., \& Reed, S. A. (2002). Audit committee effectiveness: A synthesis of the audit committee literature. Journal of Accounting Literature, 21, 38-75. https://doi.org/10.22495/cbv8i1art2

Dionne, G., \& Triki, T. (2005). Risk Management and Corporate Governance: The Importance of Independence and Financial Knowledge for the Board and the Audit Committee. SSRN Electronic Journal, 7(May). https://doi.org/10.2139/ssrn.730743

Doyle, J. T., Ge, W., \& Mcvay, S. (2007). over Financial Reporting. The Accounting Review, 82(5), 11411170.

Eisenhardt, K. M. (1989). Agency Theory: An Assessment and Review. The Academy of Management Review, 14(1), 57-74.

Ghofar, A., \& Islam, S. M. N. (2013). Analysis of the determinants and effectiveness of corporate governance: A contingency theory approach. Asian Conference on Corporate Governance and Sustainability.

Ghofar, A., \& Islam, S. M. N. (2015). Corporate Governance and Contingency Theory. Springer International Publishing Switzerland. https://doi.org/10.1007/978-3-31910996-1

Ghozali, I. (2018). Aplikasi Analisis 
Multivariete dengan Program SPSS (9th ed.). Badan Penerbit Universitas Diponegoro.

Gordon, L. A., Loeb, M. P., \& Tseng, C. Y. (2009). Enterprise risk management and firm performance: A contingency perspective. Journal of Accounting and Public Policy, 28(4), 301-327.

https://doi.org/10.1016/j.jaccpubpol.2 009.06.006

Gwenda, Z., \& Juniarti. (2013). Pengaruh Penerapan Good Corporate Governance (GCG) Pada Variabel Ukuran, Debt Ratio, dan Sektor Industri Terhadap Nilai Perusahaan. Business Accounting Review, 1(2), 137-150.

Jensen, M. C., \& Meckling, W. H. (1976). Theory of the firm: Managerial behavior, agency costs and ownership structure. Journal of Financial Economics, 305-360. https://doi.org/10.1177/00187267188 12602

Kaihatu, T. S. (2006). Good Corporate Governance dan Penerapannya di Indonesia. Jurnal Manajemen Dan Kewirausahaan, 8(1), 1-9.

Khalid, M. A., Alam, M. M., \& Said, J. (2016). Empirical assessment of good governance in the public sector of Malaysia. Economics and Sociology, 9(4), 289-304. https://doi.org/10.14254/2071789X.2016/9-4/18

Kumalasari, M., Subowo, S., \& Anisykurlillah, I. (2014). FaktorFaktor yang Berpengaruh Terhadap Luas Pengungkapan Manajemen Risiko. Accounting Analysis Journal, 3(1).

Lefort, F., \& Urzúa, F. (2008). Board independence, firm performance and ownership concentration: Evidence from Chile. Journal of Business Research, 61(6), 615-622. https://doi.org/10.1016/j.jbusres.2007 .06 .036

Liebenberg, A. P., \& Hoyt, R. E. (2003).
The Determinants of Enterprise Risk Management: Evidence From the Appointment of Chief Risk Officers. Risk Management <html_ent Glyph="@amp;" Ascii="\&amp;"/> Insurance Review, 6(1), 37-52. https://doi.org/10.1111/10981616.00019

Nocco, B. W., \& Stulz, R. M. (2006). Enterprise Risk Management: Theory and Practice. Journal of Applied Corporate Finance, 18(4), 8-20. https://doi.org/10.1111/j.17456622.2006.00106.x

Nuryaman. (2009). Pengaruh Konsentrasi Kepemilikan, Ukuran Perusahaan, Dan Mekanisme Corporate Governance Terhadap Pengungkapan Sukarela. Jurnal Akuntansi Dan Keuangan Indonesia, 6(1), 89-116. https://doi.org/10.21002/jaki.2009.05

Pagach, D., \& Warr, R. (2010). The Effects of Enterprise Risk Management on Firm Performance. SSRN Electronic Journal, April. https://doi.org/10.2139/ssrn.1155218

Power, M. (2004). The Journal of Risk Finance For Authors. The Journal of Risk Finance Iss, 5(4), 58-65. https://doi.org/10.1108/eb043451

Rosli, N. F., Mohammed, N. F., \& Sanusi, Z. M. (2017). The Determinants of Voluntary Risk Disclosures: The Case of Shariah Compliant Companies in Malaysia. SHS Web of Conferences, 36, 00002. https://doi.org/10.1051/shsconf/20173 600002

Samaha, K., Khlif, H., \& Hussainey, K. (2015). The impact of board and audit committee characteristics on voluntary disclosure: A metaanalysis. Journal of International Accounting, Auditing and Taxation, 24(March), 13-28. https://doi.org/10.1016/j.intaccaudtax. 2014.11.001

Sari, F. J. (2013). Implementasi Enterprise Risk Management Pada Perusahaan Manufaktur Di Indonesia. Accounting 
Analysis Journal, 2(2), 163-170. https://doi.org/10.15294/aaj.v2i2.144 0

Schleiver, A., \& Vishny, R. W. (1986). Large Shareholders and Corporate Control. The Journal of Political Economy, 94(3), 461-488.

Simkins, B., \& Ramirez, S. A. (2008). Enterprise-Wide Risk Management and Corporate Governance. Loyola University Chicago Law Journal, 39(Spring), 571-594.

Subramaniam, N., Mcmanus, L., \& Zhang, J. (2009). Corporate governance, firm characteristics and risk management committee formation in Australian companies. Managerial Auditing Journal, 24(4), 316-339. https://doi.org/10.1108/02686900910 948170

Suhaimi, I., \& Mohamad Naim, M. N. (2017). The Role of Board of Directors in the Establishment of Risk Management Committee. SHS Web of Conferences, 09001(June 2010), 2010-2013.

Tjahjadi, B. (2011). Hubungan sistem manajemen risiko dengan ketidakpastian lingkungan dan strategi serta dampaknya terhadap kinerja organisasi. Majalah Ekonomi, XXI(2), 142-154.

Urban, J. (2019). Corporate Governance Mechanisms: Their Strengths, Weaknesses and Complementarity. SHS Web of Conferences, 61. https://doi.org/10.1051/shsconf/20196 101028

Utomo, Y., \& Chariri, A. (2014). Determinan Pengungkapan Risiko Pada Perusahaan Nonkeuangan Di Indonesia. 03, 687-700.

Wiseman, R. M., \& Bromiley, P. (1996). Toward a Model of Risk in Declining Organizations: An Empirical Examination of Risk, Performance and Decline. Orga, 7(5).

Wu, Y. C., Kweh, Q. L., Lu, W. M., \& Azizan, N. A. (2016). The impacts of risk-management characteristics and prestige on efficiency. Journal of the Operational Research Society, 67(6). https://doi.org/10.1057/jors.2015.101

Yatim, P. (2010). Board structures and the establishment of a risk management committee by Malaysian listed firms. Journal of Management and Governance, 14(1), 17-36. https://doi.org/10.1007/s10997-0099089-6

Yunos, R. M. (2011). The Effect of Ownership Concentration, Board of Directors, Audit Commitee and Ethnicity on Conservative Accounting: Malaysian Evidence. In Edith Cowan University. https://doi.org/10.1057/978-1-34995943-3_324

Zhang, Y., Zhou, J., \& Zhou, N. (2007). Audit committee quality, auditor independence, and internal control weaknesses. Journal of Accounting and Public Policy, 26(3), 300-327. https://doi.org/10.1016/j.jaccpubpol.2 007.03.001 